\title{
Characterization of mechanothermal-synthesized hydroxyapatite-magnesium titanate composite nanopowders
}

\author{
Abbas FAHAMI*, Bahman NASIRI-TABRIZI \\ Materials Engineering Department, Najafabad Branch, Islamic Azad University, Najafabad, Isfahan, Iran
}

Received: January 13, 2013; Revised: January 30, 2013; Accepted: January 31, 2013

CThe Author(s) 2013. This article is published with open access at Springerlink.com

\begin{abstract}
Hydroxyapatite-magnesium titanate composite nanopowders have been developed using a mechanothermal process. Thermal treatment of the milled powders at $700{ }^{\circ} \mathrm{C}$ resulted in the formation of $\mathrm{HAp} / \mathrm{MgTiO}_{3}-\mathrm{MgO}$ nanocomposite. X-ray diffraction (XRD), scanning electron microscopy (SEM), transmission electron microscopy (TEM), and energy dispersive X-ray spectroscopy (EDX) techniques were utilized to characterize the synthesized powders. The results revealed that the dominant phases after mechanical activation were hydroxyapatite, anatase $\left(\mathrm{TiO}_{2}\right)$ and periclase $(\mathrm{MgO})$; while after thermal annealing process at $700{ }^{\circ} \mathrm{C}$, hydroxyapatite along with geikielite $\left(\mathrm{MgTiO}_{3}\right)$ and periclase $(\mathrm{MgO})$ were the major phases. Based on the XRD analysis, the evaluation of structural features of the samples indicated that the average crystallite sizes of hydroxyapatite after $10 \mathrm{~h}$ of milling and subsequent thermal treatment at $700{ }^{\circ} \mathrm{C}$ were about $21 \mathrm{~nm}$ and $34 \mathrm{~nm}$, respectively. Microscopic observations illustrated that the synthesized powders contained large agglomerates which consisted of significantly finer particles with spheroidal morphology. It is concluded that the mechanothermal method can be used to produce hydroxyapatite-based nanocomposite with appropriate structural and morphological features.
\end{abstract}

Keywords: $\mathrm{HAp} / \mathrm{MgTiO}_{3}-\mathrm{MgO}$; nanocomposite; characterization methods; mechanothermal

\section{Introduction}

The current development in bioceramic research is predominantly focused on calcium phosphate-based materials, as they show superior biological and mechanical properties over other materials [1-3]. Among different calcium phosphates, hydroxyapatite (HAp, $\mathrm{Ca}_{10}\left(\mathrm{PO}_{4}\right)_{6}(\mathrm{OH})_{2}$ ) has been significantly served in biomedical fields for its biocompatibility and osteoconductivity [4]. From a thermodynamic attitude, HAp is the most stable phase in physiological conditions, and also, its direct chemical boding to bone

* Corresponding author.

E-mail: ab.fahami@gmail.com is another essential feature [5]. However, these bioceramics have inherently some weaknesses such as poor toughness, low bending strength, poor corrosion resistance in acid environment, and poor chemical stability at high temperatures, which have limited their wider applications in the fields of orthopedics and dentistry [6-9]. Therefore, improvements on structural features as well as mechanical properties of hydroxyapatite have been attempted by a number of studies [10-12]. Theoretical and experimental investigations have confirmed that such properties of calcium phosphates might be remarkably strengthened by various methods, such as making nanocomposites [13], use of different sintering techniques [14], and adding dopants [11]. In the field of making nanocomposites, an ideal reinforcing material of 
calcium phosphate-based composites has not yet been found. Nevertheless, different approaches have been extensively investigated in order to develop hydroxyapatite-based composites, for instance, HAp$\mathrm{Al}_{2} \mathrm{O}_{3}$ [15], $\mathrm{HAp}-\mathrm{ZrO}_{2}$ [16] and $\mathrm{HAp}-\mathrm{TiO}_{2}$ [17] composites. These studies exhibit that interfacial reactions occur during the high temperature processing due to the large interfacial area of the composites available for the reactions. Interfacial reactions result in the formation of new phases and also affect the densification and mechanical properties. Moreover, this phenomenon even degrades the biological properties of the composites in some cases which often limit their performance [15]. Thus, production and characterization of novel $\mathrm{HAp} / \mathrm{MgTiO}_{3}-\mathrm{MgO}$ composite nanopowders provide the main target for current research. It should be noted that despite a large number of studies on the synthesis of HAp-based nanocomposites [15-20], no systematic investigation on the preparation of $\mathrm{HAp} / \mathrm{MgTiO}_{3}-\mathrm{MgO}$ is performed. Over the past decades, various synthesis methods of such biomaterials have been reported, including wet chemical method [21,22], hydrothermal process [23], solid-state reaction [24], and sol-gel method [25]. Among them, mechanothermal process has been extended for production of a wide range of advanced materials [26,27]. The prominent feature of this technique is surface melting along with the milling process which is not essential. Besides, the products have nanostructural characteristics [24].

In this paper, mechanothermal synthesis of hydroxyapatite-based nanocomposites was investigated. In addition, the effect of subsequent thermal treatment on the phase transformation was evaluated. It should be noted that nanostructural calcium phosphate-based composite with appropriate stoichiometry, high purity and crystallinity could increase the densification and osseointegrative and bioactive properties [5]. The structural features (crystallite size, lattice strain and crystallinity) as well as morphological characteristics (particle size and shape, particle distribution and agglomeration) of the nanocomposites were investigated by using XRD, SEM/EDX and TEM techniques.

\section{Experimental procedures}

\subsection{Composite preparation}

Figure 1 shows the schematic of the formation of hydroxyapatite-magnesium titanate composite nanopowders during mechanochemical process and subsequent thermal treatment. The starting reactants were anhydrous calcium hydrogen phosphate $\left(\mathrm{CaHPO}_{4}\right.$, Merck), calcium oxide (CaO, Merck), titanium dioxide $\left(\mathrm{TiO}_{2}\right.$, Merck), and magnesium (Mg, Merck). In order to preparing the composites, distinct amounts of anhydrous calcium hydrogen phosphate and calcium oxide $(\mathrm{Ca} / \mathrm{P}=1.67)$ were mixed with distinct amount of elemental magnesium and titanium dioxide powder blend $(20 \mathrm{wt} \%, \mathrm{Mg} / \mathrm{Ti}=2)$. Afterwards, the obtained mixture was milled in a high-energy planetary ball mill for $10 \mathrm{~h}$ according to the following reaction:

$$
\begin{gathered}
6 \mathrm{CaHPO}_{4}+4 \mathrm{CaO}+\mathrm{TiO}_{2}+2 \mathrm{Mg} \rightarrow \\
\mathrm{Ca}_{10}\left(\mathrm{PO}_{4}\right)_{6}(\mathrm{OH})_{2}+\mathrm{TiO}_{2}+2 \mathrm{MgO}+2 \mathrm{H}_{2}(\mathrm{~g})
\end{gathered}
$$

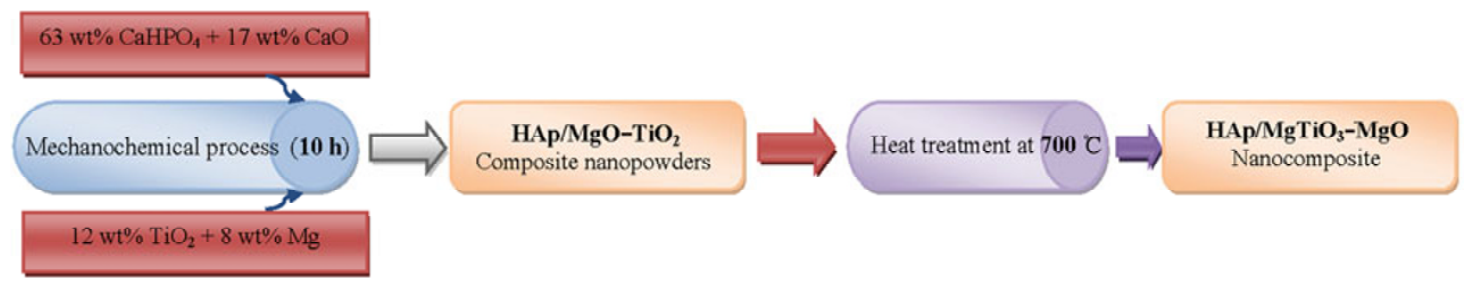

Fig. 1 Schematic of the formation of hydroxyapatite-magnesium titanate composite nanopowders during mechanochemical process and subsequent thermal treatment.

Mechanical activation was carried out in polyamide- 6 vial using zirconia balls (diameter $20 \mathrm{~mm}$ ). The ball-topowder weight ratio and milling speed were $20: 1$ and $600 \mathrm{rpm}$, respectively. It should be mentioned that the total powder mass was $6 \mathrm{~g}$. Finally, the milled powders were themal treated under air atmosphere at $700{ }^{\circ} \mathrm{C}$ for $2 \mathrm{~h}$. Details of the process specifications and abbreviated name of the specimens are presented in Table 1.
Table 1 Specifications of the synthesis process and abbreviated name of the specimens

\begin{tabular}{ccc}
\hline Sample & Composition & Process \\
\hline I & $100 \mathrm{wt} \%\left(\mathrm{CaHPO}_{4}, \mathrm{CaO}\right)$ & Milling $(10 \mathrm{~h})$ \\
II & $80 \mathrm{wt} \%\left(\mathrm{CaHPO}_{4}, \mathrm{CaO}\right)$ & Milling $(10 \mathrm{~h})$ \\
& $+20 \mathrm{wt} \%\left(\mathrm{TiO}_{2}, \mathrm{Mg}\right)$ & Milling $(10 \mathrm{~h})$ \\
III & $80 \mathrm{wt} \%\left(\mathrm{CaHPO}_{4}, \mathrm{CaO}\right)$ & $+20 \mathrm{wt} \%\left(\mathrm{TiO}_{2}, \mathrm{Mg}\right)$ \\
& + annealing $\left(700{ }^{\circ} \mathrm{C}\right.$ for $\left.2 \mathrm{~h}\right)$ \\
\hline
\end{tabular}




\section{2 Characterization techniques}

The phase evaluation of the samples was performed by XRD analysis with Xpert-Philips Diffractometer using $\mathrm{Cu} \mathrm{K} \alpha$ radiation. The diffractometer was operated at $40 \mathrm{kV}$ and $30 \mathrm{~mA}$. During the X-ray diffractometery, the step size was $0.05^{\circ}$. All measurements were performed at room temperature with the diffraction range of $2 \theta=20^{\circ}-60^{\circ}$. The diffraction patterns of the samples were compared to the standards compiled by Joint Committee on Powder Diffraction and Standards (JCPDS), which involved cards 09-0432 for HAp, 04-0829 for MgO, 021-1272 for $\mathrm{TiO}_{2}$, and 06-0494 for $\mathrm{MgTiO}_{3}$. Average crystallite sizes and lattice strains of the samples were determined by using the XRD data according to the following equations [26]:

$$
\begin{gathered}
D=\frac{K \lambda}{\left(b_{\text {obs }}-b_{\text {std }}\right) \cos \theta} \\
E^{2}=\frac{\left(b_{\text {obs }}^{2}-b_{\text {std }}^{2}\right)}{(4 \tan \theta)^{2}}
\end{gathered}
$$

where $b, K, \lambda, D, E$, and $\theta$ are the structural broadening (in radian), the shape coefficient (value between 0.9 and 1.0), the wavelength of the X-ray used $(0.154056 \mathrm{~nm})$, the crystallite size, the lattice strain, and Bragg angle $\left({ }^{\circ}\right)$, respectively.

From another point of view, the fraction of crystalline phase $\left(X_{\mathrm{c}}\right)$ in HAp was evaluated by the following equation [28]:

$$
X_{\mathrm{c}}=\left(\frac{K}{B}\right)^{3}
$$

where $K$ and $B$ are the constants equal to 0.24 and full width at half maximum (FWHM) $\left(^{\circ}\right)$ of the selected reflection peaks, respectively. It should be noted that the average of the fraction of crystalline phase $\left(X_{\mathrm{c}}\right)$ in HAp was determined by using two groups of peaks; one group was (211), (112) and (300) which related to HAp.

Energy dispersive X-ray spectroscopy (EDX) coupled to SEM was used to the semi-quantitative test of the products. The morphological characteristics of the samples which were sputter-coated with a thin layer of gold were examined by a scanning electron microscope (SEM, SERON AIS-2100, Republic of Korea). The size and morphology of powders at temperature of $700{ }^{\circ} \mathrm{C}$ were surveyed in a transmission electron microscope (TEM, Philips CM10, Eindhoven, the Netherlands) which operated at $100 \mathrm{kV}$.

\section{Results and discussion}

\subsection{XRD analysis}

\section{1. 1 Phase determination}

Figure 2 illustrates the XRD spectra of the samples after mechanical activation and subsequent thermal treatment at temperature of $700{ }^{\circ} \mathrm{C}$. Figure 2(a) shows the well characterized peaks of pure HAp and the peaks are indexed according to the standard pattern (JCPDS 09-0432). In this sample, diffraction peaks were broadened, particularly between $2 \theta=31^{\circ}-35^{\circ}$, indicating that the sample demonstrated poor crystallinity (low fraction of crystalline phase).

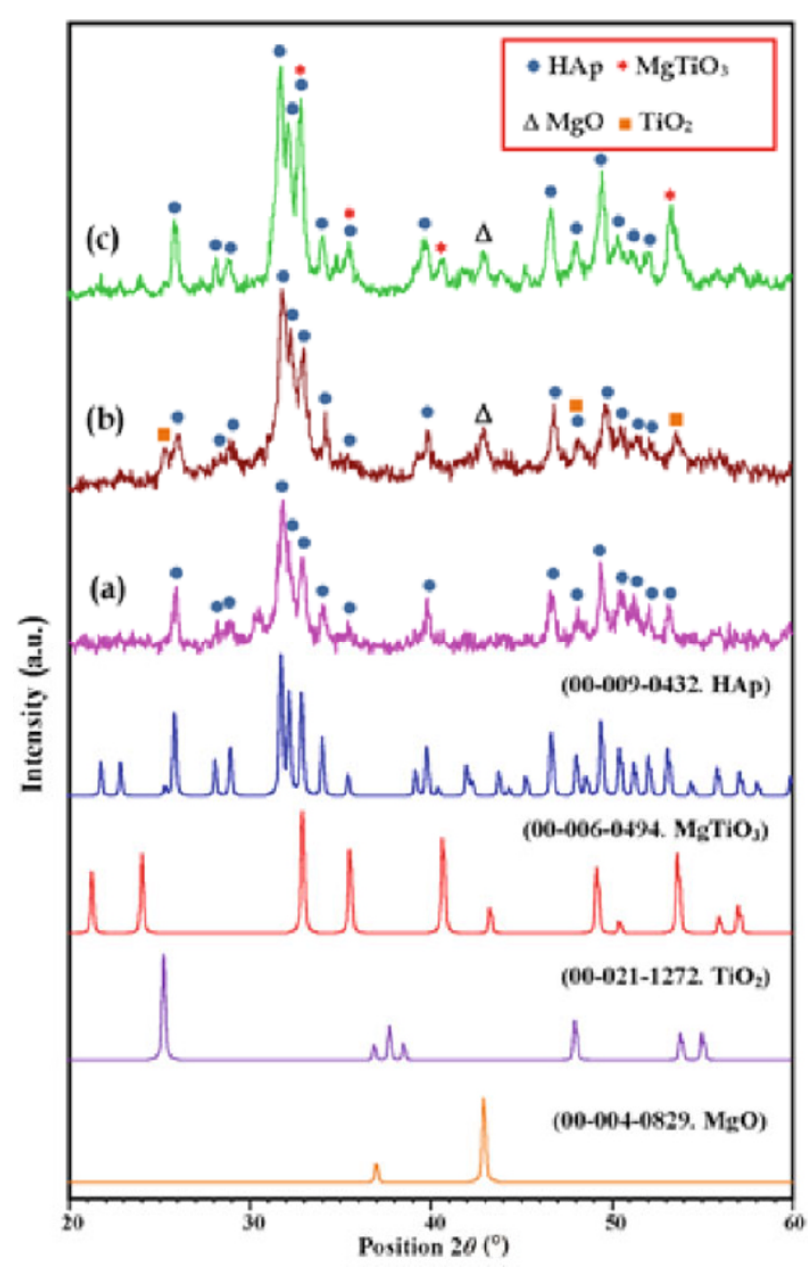

Fig. 2 XRD patterns of the samples: (a) HAp after $10 \mathrm{~h}$ of milling; (b) $\mathrm{HAp} / \mathrm{MgO}-\mathrm{TiO}_{2}$ after $10 \mathrm{~h}$ of milling; (c) $\mathrm{HAp} / \mathrm{MgTiO}_{3}-\mathrm{MgO}$ after $10 \mathrm{~h}$ of milling + thermal treatment at $700{ }^{\circ} \mathrm{C}$. 
Therefore, the product of mechanochemical process (reaction (5)) between $\mathrm{CaHPO}_{4}$ and $\mathrm{CaO}$ is pure $\mathrm{HAp}$ according to the following reaction:

$$
6 \mathrm{CaHPO}_{4}+4 \mathrm{CaO} \rightarrow \mathrm{Ca}_{10}\left(\mathrm{PO}_{4}\right)_{6}(\mathrm{OH})_{2}+2 \mathrm{H}_{2} \mathrm{O}(\mathrm{g})
$$

The peaks of Sample II (Fig. 2(b)) correspond to $\mathrm{HAp}$ as a major phase with anatase $\left(\mathrm{TiO}_{2}\right)$ and periclase $(\mathrm{MgO})$ as minor phases. This phenomenon indicates that the product of mechanochemical process in presence of $\mathrm{TiO}_{2}$ and $\mathrm{Mg}(20 \mathrm{wt} \%)$ was $\mathrm{HAp} / \mathrm{MgO}-\mathrm{TiO}_{2}$ composite. From Fig. 2(c) it is verified the existence of HAp and geikielite $\left(\mathrm{MgTiO}_{3}\right)$ phases together with minor $\mathrm{MgO}$ phase after the annealing at $700{ }^{\circ} \mathrm{C}$. It is clearly seen that the thermal treatment at $700{ }^{\circ} \mathrm{C}$ leads to the formation of $\mathrm{MgTiO}_{3}$ by the following reaction:

$$
\begin{gathered}
\mathrm{MgO}+\mathrm{TiO}_{2} \rightarrow \mathrm{MgTiO}_{3} \\
\Delta G_{298 \mathrm{~K}}=-25.410 \mathrm{~kJ}, \Delta H_{298 \mathrm{~K}}=-26.209 \mathrm{~kJ}
\end{gathered}
$$

It was reported that the decomposition temperature $\left(600-800{ }^{\circ} \mathrm{C}\right)$ strongly depends on the preparation method of the HAp powders [12]. Thus, the annealing temperature must be selected $\leqslant 700{ }^{\circ} \mathrm{C}$ if the purpose is to achieve pure HAp without the presentation of any extra biocompatible phases. Moreover, a patent reported the biocompatibility and osteoconductivity of magnesium titanate oxide film implanted for utilizing in several medical fields such as dentistry, orthopedics, maxillofacial and plastic surgery [29]. Therefore, the presence of $\mathrm{MgO}$ and $\mathrm{MgTiO}_{3}$ phases along with $\mathrm{HAp}$ and in outputs can increase the biological and mechanical properties of calcium phosphate-based nanocomposite. For all these results, we reach an important conclusion that applying appropriate mechanochemical process and subsequent thermal treatment can cause the formation of calcium phosphate-based nanocomposite which may improve the structural features as well as morphological properties of calcium phosphate. In the following section we provide a brief overview of the structural features of the samples.

\subsection{Structural features}

In order to investigate the effect of milling and subsequent thermal treatment on the formation of crystalline phases, the fraction of crystalline phase of the specimens was determined by using the XRD profiles. Figure 3 shows the variation in the XRD profiles in 3D-view mode for samples during milling and after thermal treatment at $700{ }^{\circ} \mathrm{C}$. In this paper, crystallinity was expressed in accordance with the line broadening at the (211), (112) and (300) diffraction peaks. As can be seen in Figs. 3(a)-3(c), poor crystalline apatite phase was obtained after $10 \mathrm{~h}$ of milling (Sample I); while in presence of $20 \mathrm{wt} \%$ elemental magnesium and titanium dioxide powder blend (Sample II), the crystallinity rapidly increased and the fraction of crystalline phase of HAp reached about 0.54. Finally, high crystalline HAp-based composite was produced after annealing at $700{ }^{\circ} \mathrm{C}$ (Sample III). Since crystallinity is principally determined by the two main factors of crystallite size and residual elastic strain, the average crystallite size and lattice strain of the samples were examined (Fig. 4). Based on Figs. 4(a) and 4(b), the lattice strain of HAp powders rapidly increased and reached about $0.604 \%$ after $10 \mathrm{~h}$ of milling. The low fraction of crystalline phase of HAp was due to the crystal strain and refinement of crystals. On the contrary, the breadth of fundamental diffraction peaks decreased after the thermal treatment as compared to the results for the milled powders. This phenomenon can be attributed to an increase in the fraction of crystalline phase, which is due to the increase of crystallite size and the decrease of lattice strain. The calculated amounts of
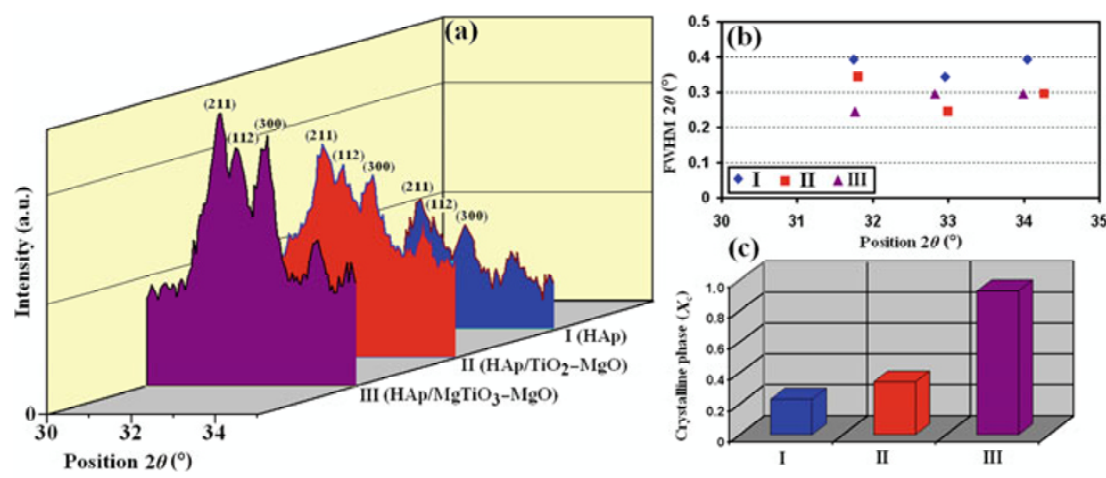

Fig. 3 Variation in XRD profiles in 3D-view mode for samples during milling and after thermal treatment at $700{ }^{\circ} \mathrm{C}$. 
structural features indicated that increasing the annealing temperature might assist grain growth, so all the powders were comprised of nano-sized crystallites. Hence, annealing temperature plays an important role on structural features of calcium phosphate-based nanocomposite.
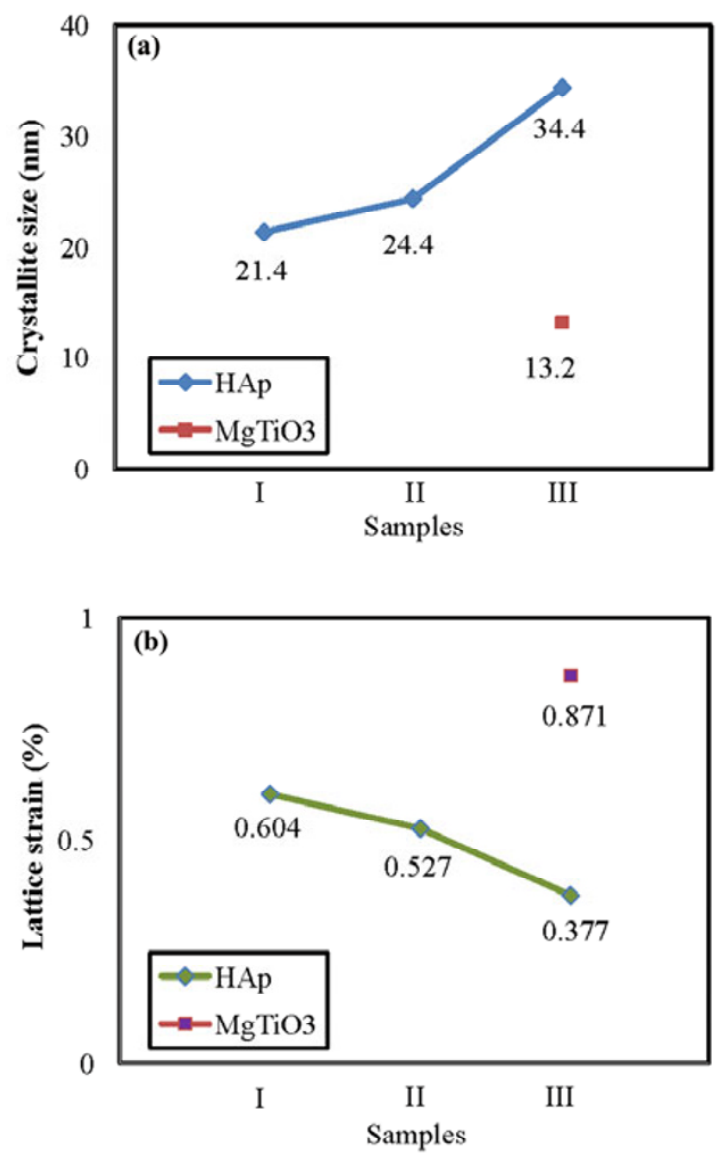

Fig. 4 Average crystallite size and lattice strain of the samples before and after thermal treatment.

\section{2 EDX analysis}

Energy dispersive X-ray spectroscopy (EDX) has been performed to confirm that the products from the proposed synthesis processes are HAp-based composites. Figure 5 represents the EDX results for HAp-based composites which were synthesized after $10 \mathrm{~h}$ of milling and subsequent thermal treatment at $700{ }^{\circ} \mathrm{C}$. EDX data show that the main elements of the calcium phosphate-based composite nanopowders were calcium, phosphorus, oxygen, magnesium, and titanium. The results of measurements of elemental composition and ratios by EDX method indicate a higher $\mathrm{Ca} / \mathrm{P}$ ratio in small area compared to $\mathrm{Mg} / \mathrm{Ti}$ ratio which is agreed with the chemical composition of powder mixture. Further, chemically stable contaminants are not detected due to the excessive adhesion of powders to the vial and balls. It should be noted that the use of polymeric milling vial has been suggested in the authors' experiment not only to annihilate contamination problem, but also to achieve modified morphologies with high biomedical performance [10].
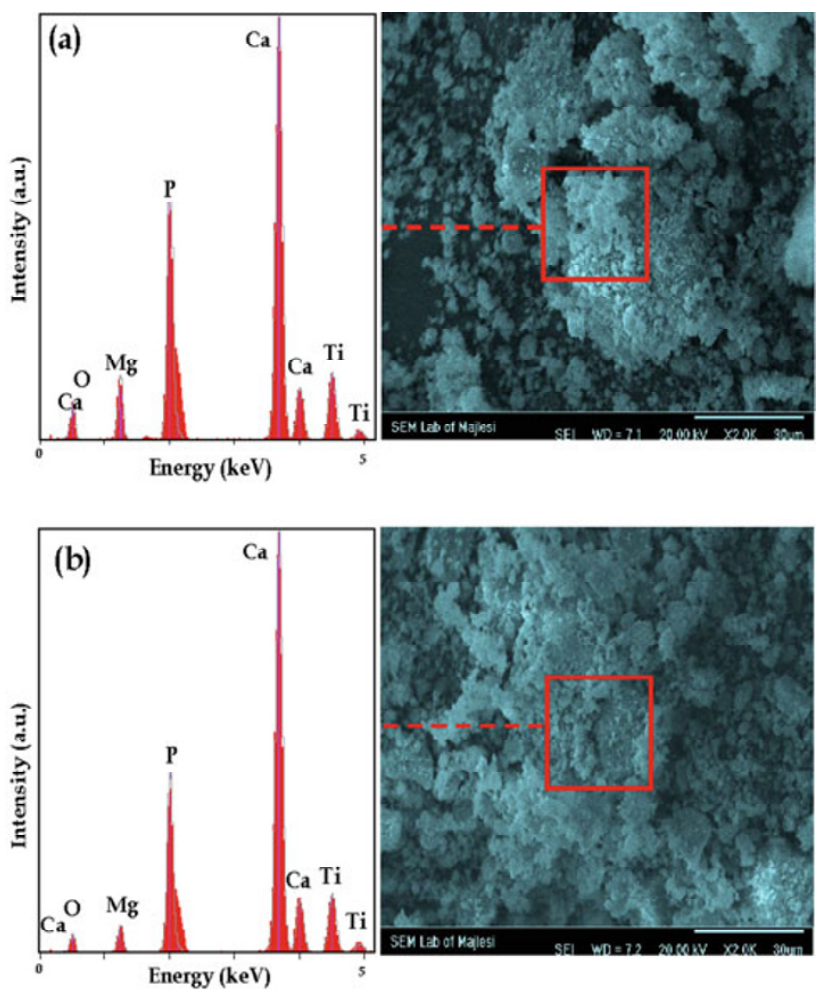

Fig. 5 EDX results of the samples: (a) $\mathrm{HAp} / \mathrm{MgO}-\mathrm{TiO}_{2}$ after $10 \mathrm{~h}$ of milling; (b) $\mathrm{HAp} / \mathrm{MgTiO}_{3}-\mathrm{MgO}$ after $10 \mathrm{~h}$ of milling + thermal treatment at $700{ }^{\circ} \mathrm{C}$.

\section{3 SEM and TEM observations}

According to the fact that the hydroxyapatite with appropriate morphological characteristics have better functions in biomedical applications [10], the morphological features as an important aspect of bioceramics were evaluated by using SEM and TEM techniques. Figure 6 shows the SEM micrographs of the samples after milling and thermal treatment at $700{ }^{\circ} \mathrm{C}$. As can be seen in Fig. 6(a), a very fine structure was formed after $10 \mathrm{~h}$ of milling. After thermal treatment at $700{ }^{\circ} \mathrm{C}$ (Fig. 6(b)), continuous evolution of the morphological features was appeared. The mean size of the powder particles increased after thermal treatment; however, only a slight change in 
particle size was observed in heat-treated sample at $700{ }^{\circ} \mathrm{C}$ compared to the milled powders. After milling and subsequent thermal treatment at $700{ }^{\circ} \mathrm{C}$, the products were composed of fine particles with a mean particle size of about $482 \mathrm{~nm}$ and $510 \mathrm{~nm}$, respectively (Figs. 6(a) and 6(b)). The SEM observations indicate that increasing the annealing temperature might assist grain growth due to the lack of any obstacle for particle growth.
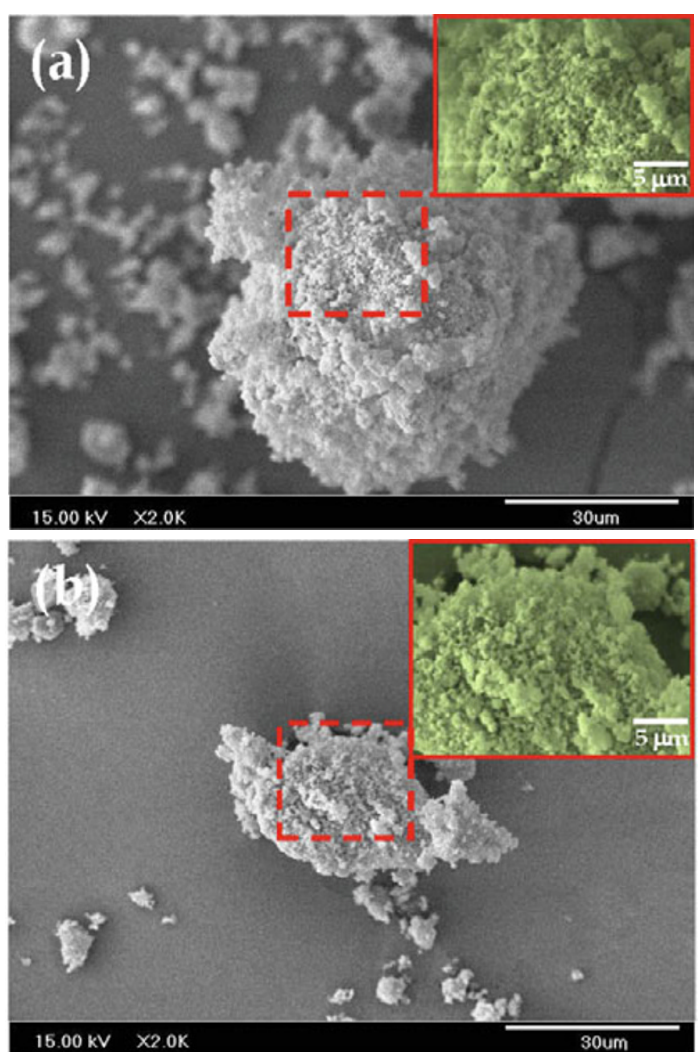

Fig. 6 SEM micrographs of the samples: (a) $\mathrm{HAp} / \mathrm{MgO}-\mathrm{TiO}_{2}$ after $10 \mathrm{~h}$ of milling; (b) $\mathrm{HAp} / \mathrm{MgTiO}_{3}-\mathrm{MgO}$ after $10 \mathrm{~h}$ of milling + thermal treatment at $700{ }^{\circ} \mathrm{C}$.

Typical TEM images of hydroxyapatite-magnesium titanate nanocomposite produced after $10 \mathrm{~h}$ of milling and subsequent thermal treatment at $700{ }^{\circ} \mathrm{C}$ are shown in Fig. 7. From TEM observations, the particles show high tendency to agglomerate. According to literature [30], when two adjacent primary particles collide, the coalescence may take place on the premise that these two particles share a common crystallographic orientation. Hence, two primary particles attach to each other and combine into a secondary one. Since the sizes of the secondary particles are still very small, it is reasonable that they will continue to collide and coalesce which may ultimately lead to the agglomeration. In Fig. 7, it can be seen that the agglomerates with mean size of about $322 \mathrm{~nm}$ were developed after thermal treatment at $700{ }^{\circ} \mathrm{C}$. In this sample, the cluster-like shape particles were composed of fine spheroidal shape crystals with a mean size of about $55 \mathrm{~nm}$. It should be mentioned that chemical interactions at the contacting surface of crystals resulted in cluster-like shape aggregates which were composed of fine spheroidal-shape crystals. This phenomenon is referred to the nature of milling process which originates through repeated welding, fracturing and re-welding of fine powder particles $[26,27]$.

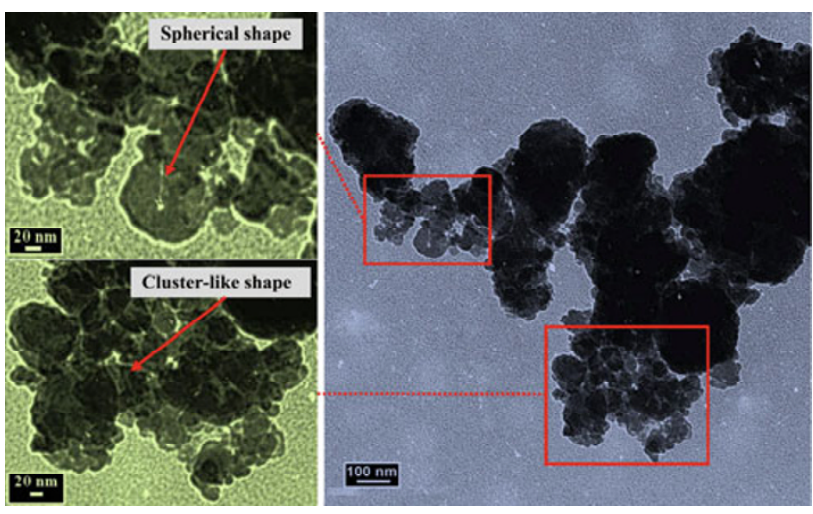

Fig. 7 TEM images of the sample: HAp/ $\mathrm{MgTiO}_{3}-\mathrm{MgO}$ after $10 \mathrm{~h}$ of milling + thermal treatment at $700{ }^{\circ} \mathrm{C}$.

The above-mentioned results suggest that the one-step mechanochemical process followed by thermal treatment is an effective route for producing nanostructural hydroxyapatite-magnesium titanate nanocomposite with appropriate structural features as well as morphological characteristics.

\section{Conclusions}

Hydroxyapatite-magnesium titanate composite nanopowders with appropriate structural features as well as morphological characteristics were synthesized via one-step mechanochemical process and subsequent thermal treatment. According to the XRD data, thermal annealing of the milled powders at $700{ }^{\circ} \mathrm{C}$ resulted in the formation of HAp-based nanocomposites with different structural features. The calculated amounts of crystallite size indicated that increasing the annealing temperature might assist grain growth, although all the 
composite powders were in the nano-sized range. In addition, no chemically stable contaminants were detected due to the excessive adhesion of powders to the vial and balls. The SEM and TEM observations revealed that the sample annealed at $700{ }^{\circ} \mathrm{C}$ exhibited small grains with a mean size of about $55 \mathrm{~nm}$. The results confirm that if an appropriate thermal treatment be selected after mechanochemical process, hydroxyapatite-magnesium titanate nanocomposite with suitable characteristics can be obtained.

\section{Acknowledgements}

The authors are grateful to research affairs of Islamic Azad University, Najafabad Branch, for supporting this research.

Open Access: This article is distributed under the terms of the Creative Commons Attribution Noncommercial License which permits any noncommercial use, distribution, and reproduction in any medium, provided the original author(s) and source are credited.

\section{References}

[1] $\mathrm{Xu} \mathrm{Q}, \mathrm{Lu}$ GJ, Bian XJ, et al. Calcium phosphate-gold nanoparticles nanocomposite for protein adsorption and mediator-free $\mathrm{H}_{2} \mathrm{O}_{2}$ biosensor construction. Mat Sci Eng C 2012, 32: 470-477.

[2] Farzadi A, Solati-Hashjin M, Bakhshi F, et al. Synthesis and characterization of hydroxyapatite/ $\beta$-tricalcium phosphate nanocomposites using microwave irradiation. Ceram Int 2011, 37: 65-71.

[3] Schneider OD, Stepuk A, Mohn D, et al. Light-curable polymer/calcium phosphate nanocomposite glue for bone defect treatment. Acta Biomater 2010, 6: 2704-2710.

[4] Kalita SJ, Bhardwaj A, Bhatt HA. Nanocrystalline calcium phosphate ceramics in biomedical engineering. Mat Sci Eng C 2007, 27: 441-449.

[5] Sanosh KP, Chu MC, Balakrishnan A, et al. Sol-gel synthesis of pure nano sized $\beta$-tricalcium phosphate crystalline powders. Curr Appl Phys 2010, 10: 68-71.

[6] Choi D, Kumta PN. Mechano-chemical synthesis and characterization of nanostructured $\beta$-TCP powder. Mat Sci Eng C 2007, 27: 377-381.

[7] Pushpakanth S, Srinivasan B, Sreedhar B, et al. An in situ approach to prepare nanorods of titania-hydroxyapatite $\left(\mathrm{TiO}_{2}-\mathrm{HAp}\right)$ nanocomposite by microwave hydrothermal technique. Mater Chem Phys 2008, 107: 492-498.

[8] Fini M, Savarino L, Aldini NN, et al. Biomechanical and histomorphometric investigations on two morphologically differing titanium surfaces with and without fluorohydroxyapatite coating: An experimental study in sheep tibiae. Biomaterials 2003, 24: 3183-3192.

[9] Chen YM, Miao XG. Thermal and chemical stability of fluorohydroxyapatite ceramics with different fluorine contents. Biomaterials 2005, 26: 1205-1210.

[10] Nasiri-Tabrizi B, Honarmandi P, EbrahimiKahrizsangi $\mathrm{R}$, et al. Synthesis of nanosize single-crystal hydroxyapatite via mechanochemical method. Mater Lett 2009, 63: 543-546.

[11] Cacciotti I, Bianco A, Lombardi M, et al. Mg-substituted hydroxyapatite nanopowders: Synthesis, thermal stability and sintering behavior. $J$ Eur Ceram Soc 2009, 29: 2969-2978.

[12] Ebrahimi-Kahrizsangi R, Nasiri-Tabrizi B, Chami A. Characterization of single-crystal fluorapatite nanoparticles synthesized via mechanochemical method. Particuology 2011, 9: 537- 544.

[13] Fahami A, Ebrahimi-Kahrizsangi R, Nasiri-Tabrizi B. Mechanochemical synthesis of hydroxyapatite/ titanium nanocomposite. Solid State Sci 2011, 13: 135-141.

[14] Gu YW, Loh NH, Khor KA, et al. Spark plasma sintering of hydroxyapatite powders. Biomaterials 2002, 23: 37-43.

[15] Viswanath B, Ravishankar N. Interfacial reactions in hydroxyapatite/alumina nanocomposites. Scripta Mater 2006, 55: 863-866.

[16] Rao RR, Kannan TS. Synthesis and sintering of hydroxyapatite-zirconia composites. Mat Sci Eng C 2002, 20: 187-193.

[17] Nath S, Tripathi R, Basu B. Understanding phase stability, microstructure development and biocompatibility in calcium phosphate-titania composites, synthesized from hydroxyapatite and titanium powder mixture. Mat Sci Eng C 2009, 29: 97-107.

[18] Jin HH, Min SH, Song YK, et al. Degradation behavior of poly (lactide-co-glycolide) $/ \beta$-TCP composites prepared using microwave energy. Polym Degrad Stabil 2010, 95: 1856-1861.

[19] Cao H, Kuboyama N. A biodegradable porous composite scaffold of PGA $/ \beta$-TCP for bone tissue engineering. Bone 2010, 46: 386-395.

[20] Hu HJ, Liu XY, Ding CX. Preparation and in vitro 
evaluation of nanostructured $\mathrm{TiO}_{2} / \mathrm{TCP}$ composite coating by plasma electrolytic oxidation. $J$ Alloys Compd 2010, 498: 172-178.

[21] Mobasherpour I, Heshajin MS, Kazemzadeh A, et al. Synthesis of nanocrystalline hydroxyapatite by using precipitation method. J Alloys Compd 2007, 430: 330-333.

[22] Kivrak N, Tas AC. Synthesis of calcium hydroxyapatite-tricalcium phosphate (HA-TCP) composite bioceramic powders and their sintering behavior. J Am Ceram Soc 1998, 81: 2245-2252.

[23] Liu F, Wang FP, Shimizu T, et al. Hydroxyapatite formation on oxide films containing $\mathrm{Ca}$ and $\mathrm{P}$ by hydrothermal treatment. Ceram Int 2006, 32: 527-531.

[24] Silva CC, Pinheiro AG, Miranda MAR, et al. Structural properties of hydroxyapatite obtained by mechanosynthesis. Solid State Sci 2003, 5: 553-558.

[25] Balamurugan A, Kannan S, Rajeswari S. Bioactive sol-gel hydroxyapatite surface for biomedical
application-In vitro study. Trends Biomater Artif Organs 2002, 16: 18-20.

[26] Suryanarayana C. Mechanical alloying and milling. Prog Mater Sci 2001, 46: 1-184.

[27] De Castro CL, Mitchell BS. Nanoparticles from mechanical attrition. In Synthesis Functionalization and Surface Treatment of Nanoparticles. Baraton MI, ed. USA: American Scientific Publishers, 2003.

[28] Landi E, Tampieri A, Celotti G, et al. Densification behavior and mechanisms of synthetic hydroxyapatites. $J$ Eur Ceram Soc 2000, 20: 2377-2387.

[29] Sul YT. Osseoinductive magnesium-titanate implant and method of manufacturing the same. U.S. Patent 7 452 566, Nov. 2008.

[30] Zhang J, Lin Zh, Lan YZ, et al. A multistep oriented attachment kinetics: Coarsening of $\mathrm{ZnS}$ nanoparticle in concentrated NaOH. J Am Chem Soc 2006, 128: 12981-12987. 